\title{
PEMIKIRAN PENDIDIKAN ISLAM YANG MEMBEBASKAN
}

\author{
Yusuf Hasan Baharudin \\ Universitas Nahdlatul Ulama Al Ghazali Cilacap \\ Email: bjhasan.bk@unugha.id
}

\begin{abstract}
Education is the most effective means to liberate and liberate humans from all forms of exploitation and dehumanization. Education should be open to renewal and dialogue. However, until now the reality is that there are still many educational processes that are monological in nature. As a result, human nature or basic potential possessed by students cannot grow and develop following expectations because the process of student growth and development essentially needs to have a humanizing process in the world of education. This concept of education is known as liberating education, namely education that places a communicative or dialogical atmosphere so that an educational atmosphere that is more alive and human will be created. Liberating learning can be optimal if teachers and students can jointly create conducive learning conditions, teachers and students feel free or independent from the crush of expressing their conscience, feelings and ideology. Liberating Islamic education is an educational process that upholds human nature and places a dialogical, communicative atmosphere to create a more lively and humane atmosphere.
\end{abstract}

Keywords: Islamic education that is liberating, dialogical, monologic

\section{A. Pendahuluan}

Pemikiran dalam Islam akan selalu relevan dan pantas dibicarakan manakala proses kehidupan ini masih tetap berlangsung utamanya dalam hal pendidikan. Pemikiran Islam dalam pendidikan akan selalu berkembang dinamis dan menglami perubahan sesuai dengan zamannya. Pada hakekatnya pendidikan Islam adalah sesuatu yang luhur karena di dalamnya mengandung nilai-nilai kebajikan yang normatif. Pendidikan bukan hanya kegiatan belajar mengajar atau transfer knowledge, tetapi juga sebagai proses penyadaran untuk menjadikan manusia sebagai "manusia" yang berakhlak dan mengembangkan potensinya yang berasaskan Qur'an dan Hadis.

Penddidikan merupakan pergumulan yang tidak akan pernah selesai dan selalu melekat dengn zamannya. Malik Fajar (2002) pernah mengemukakan tentng hal ini yakni didiklah anakmu sesuai dengan 
zamannya karena dia dilahirkan bukan pada zamanmu. Pesan yang dikemukakan ditujukan untuk para tenaga pendidik bahwasannya pendidikan bukanlah barang mati yang tidak bisa mengalami perubahan. Permasalahan pendidikan berkaitan pula dengn permasalahn kehidupan dalam berbagai aspeknya. Sehingga guru harus menghidupkan interaksi dalam pembelajarannya, dengan misi utama memandirikan siswanya. Sistem yang seperti ini diharapkan melahirkan suasana pendidikan yang komunikatif atau dialogis sehingga pendidikan lebih hidup dan manusiawi.

Namun, dewasa ini pendidikan dianggap kaku, tidak bebas dan mematikan kreativitas siswa. Masalah ini muncul ketika tujuan, materi, metode dan lain sebagainya. Pada tujuan misalnya, tujuan dari pendidikan Islam Indonesia yaitu berperan dalam menumbuhkan, meningkatkan, menghayati dan mengamalkan ajaran-ajaran Islam dalam berbagai aspek dan bidang, untuk mengisi kehidupan sehari-hari sehingga senantiasa bertaqwa kepada Alloh SWT dalam konteks pribadi maupun sosial kemasyarakatan, berbangsa dan bernegara.

Namun, pendidikan Islam selama ini lebih dikedepankan aspek hafalan-hafalan atau pengetahuan daripada nilai-nilai yang bersifat penghayatan dan pengamalan, tanpa melibatkan seleruhuh komponen kecerdasan yaitu kognitif, afektif dan psikomotorik. Padahal, setidaknya ada empat tujuan yang menjadi idealisme pendidikan yaitu memperoleh pengetahuan dan keterampilan (kompetensi); orientasi humanistik, menjawab tantangan sosial, ekonomi dan masalah keadilan serta kemajuan ilmu-ilmu itu sendiri. Ini jelas bahwa dalam melaksanakan tujuan yang kedua, ketiga dan keempat belum mendapat perhatian secara baik. Keempat tujuan ini menentukan bentuk kompetensi yang dihasilkan dan juga model komunikasi dalam proses pembelajaran yang akan diterapkan.

\section{B. Pembahasan}

\section{Konsep Pendidikan yang Membebaskan/Memerdekakan Menurut Paulo Freire}

Pendidikan merupakan usaha untuk memerdekakan manusia, sedangkan pendidikan menurut Paulo Freire merupakan usaha untuk mengembalikan fungsi pendidikan sebagai alat yang memerdekakan manusia dari berbagai bentuk penindasan dan ketertindasan, atau bisa disebut dengan usaha untuk "memanusiakan manusia" (ngewongke/humanisasi). Dengan menggunakan pendekatan humanis, ia membangun konsep pendidikannya mulai dari konsep manusia sebagai subyek aktif. Manusia adalah makhluk praksis, yakni makhluk yang dapat beraksi dan berefleksi dengan menggunakan pikirannya. 
Pendidikan dengan pendekatan kemanusiaan sering diidentikan dengan pembebasan, yakni pembebasan dari hal-hal yang tidak manusiawi. Jadi, untuk mewujudkan pendidikan yang memanusiakan manusia diperlukan suatu pendidikan yang membebaskan dari unsur dehumanisasi. Dehumanisasi tersebut bukan hanya menandai seseorang yang kemanusiannya telah dirampas, melainkan (dalam cara yang berlainan) menandai pihak yang telah merampas kemanusiaan itu, dan merupakan pembengkokkan cita-cita untuk menjadi manusia yang lebih utuh.

Konsep pendidikan Paulo Freire berpijak pada penghargaan terhadap manusia. Pendidik dan peserta didik ditempatkan sebagai subyek dalam proses pendidikan, karena mereka memiliki kedudukan yang sejajar. Pendidikan adalah sebuah kegiatan belajar bersama antara pendidik dan peserta didik dengan perantara dunia, oleh objek-objek yang dapat dikenal. Pendidikan bukan lagi sekedar pengajaran, namun komunikasi antara para peserta didik dan pendidik yang juga belajar. Keduanya bertanggung jawab bersama atas proses pencapaian tujuan. Hal ini merupakan sebuah penghargaan terhadap peserta didik sebagai human. Pendidikan bukan lagi proses transfer of knowlage, sebab keduanya sama-sama dalam suasana dialogis membuka cakrawala realita dunia.

"Tujuan utama manusia adalah humanisasi yang ditempuh melalui pembebasan. Proses untuk menjadi manusia secara penuh hanya mungkin apabila manusia berintegrasi dengan dunia. Dalam kedudukannya sebagai subjek, manusia senantiasa menghadapi berbagai ancaman dan tekanan, namun ia tetap mampu terus menapaki dan menciptakan sejarah berkat refleksi kritisnya."152

Hakekat pendidikan Paulo Freire diarahkan atas pandangannya terhadap manusia dan dunia, pendidikan harus fokus pada pengenalan realitas diri manusia dan dirinya sendiri, serta mempunyai kesadaran dan berpotensi sebagai man of action untuk mengubah dunianya. Pendidikan adalah instrumen pembebasan manusia supaya mampu mewujudkan potensinya. Oleh karena itu, pendidikan memiliki posisi strategis untuk membawa manusia kepada kehidupan yang bermartabat dan berkualitas.

Sayangnya, gambaran dunia pendidikan secara umum masih jauh dari ideal. Sebagian besar sekolah (di Indonesia khususnya) hanya berorientasi pada target kuantitatif yang bisa diukur, seperti misalnya harus lulus mata pelajaran dengan nilai tertentu, mendapatkan trophy, dan lain sebagainya. Padahal, model pendidikan seperti itu jelas menimbulkan efek yang kurang baik bagi peserta didik. Menurut Paulo

1 Paulo Freire dalam Siti Murtiningsih, Pendidikan Alat Perlawanan: Teori Pendidikan Radikal Paulo Freire, (Yogyakarta: Resist Book, 2004), h. 55. 
Freire dalam bukunya yang berjudul Pendidikan Kaum Tertindas (1994), model pendidikan yang semacam itu ia sebut sebagai banking education alias pendidikan gaya bank.

"Pendidikan menjadi sebuh kegiatan menabung, di mana para peserta didik adalah celengan dan pendidik adalah penabungnya. Yang terjadi bukanlah proses komunikasi, tetapi pendidik menyampaikan pernyataan-pernyataan dan "mengisi tabungan" yang diterima, dihafal dan diulangi dengan patuh oleh para peserta didik."153

Dalam pendidikan gaya bank seperti ini, peserta didik hanya dijejeli dengan ilmu secara satu arah dengan tujuan mendapatkan nilai-nilai kuantitatif yang dituju. Praktek pendidikan hanya dipahami sebatas sarana pewarisan ilmu. Pendidikan tidak dipahami sebagai transformasi ilmu pengetahuan dan nilai-nilai yang lebih menekankan pada proses pendewasaan pemikiran dan mengartikan belajar sebagai proses memaknai dan mengkritisi realitas sosial yang ada di lingkungan sekitar. Bukan hanya mencari ijazah dengan nilai yang tinggi maupun sebagai sarana meningkatkan status sosial.

"Dalam konsep pendidikan gaya bank, pengetahuan merupakan sebuah anugrah yang dihibahkan oleh mereka yang menganggap diri berpengetahuan kepada mereka yang dianggap tidak memiliki pengetahuan apa-apa."154

Pendidikan gaya bank inilah yang sudah menjadi instrumen untuk menindas kesadaran akan realitas yang sejati dan menyebabkan seseorang menjadi pasif dan menerima begitu saja keberadaannya. Pendidikan gaya bank tidak akan mendorong peserta didik untuk secara kritis mempertimbangkan realitas. Peserta didik hanya akan menjadi penerima yang pasif dari realitas yang diberikan, tanpa pernah bisa mempertanyakan kevalidan kebenaran atau kebergunaan realitas yang diajarkan kepada dirinya. Yang disebut keberhasilan dalam metode ini adalah ketika peserta didik dapat menghafalkan dengan baik semua pengetahuan yang telah didepositokan ke dalam dirinya.

\section{Pendidikan Islam yang Membebaskan}

Tokoh Islam Aisyah Bintu Syati (Manusia dalam Persfektip AlQur'an), Prof. DR. H. Ramayulis dan DR. Samsul Nizar, MA. (Filsafat Pendidikan Islam) mengemukakan bahwa teori pendidikan pembebasan ada empat kebebasan yang merupakan hak bagi setiap individu, diantaranya adalah: (1) merdeka dari perbudakan, (2) merdeka dalam beraqidah, (3) merdeka dalam berpikir dan mengemukakan pendapatnya dan (4) merdeka dalam berkehendak. Kebebasan-kebebasan ini

2 Paulo Freire, Pendidikan Kaum Tertindas, (Jakarta: LP3S, 2008), h. 52.

3 Paulo Freire dalam Siti Murtiningsih, Pendidikan Alat Perlawanan..., h. 53. 
mendasarkan pada beberapa ayat dalam Al-Qur'an yang merupakan sumber utama bagi ummat Islam. Diantara ayat-ayat tersebut adalah Alqur' an surat Al-Imran ayat 79:

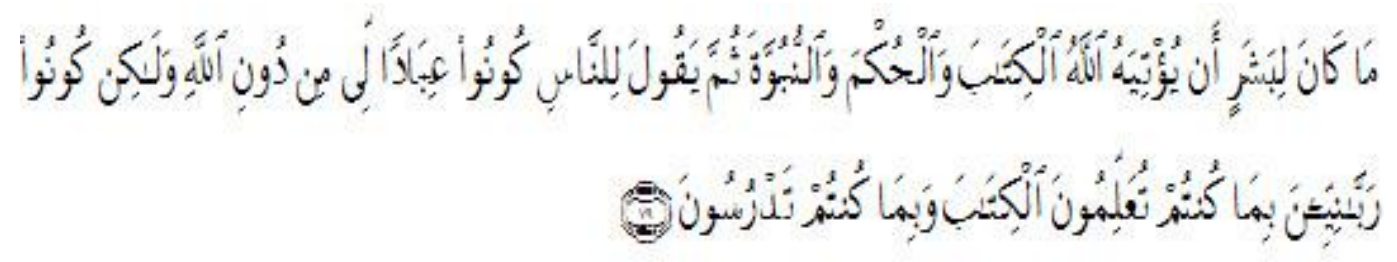

Artinya: tidak wajar bagi seseorang manusia yang Allah berikan kepadanya Al Kitab, Hikmah dan kenabian, kemudian Dia berkata kepada manusia: "Hendaklah kamu menjadi penyembah-penyembahku bukan penyembah Allah." akan tetapi (dia berkata): "Hendaklah kamu menjadi orang-orang rabbani[208], karena kamu selalu mengajarkan Al kitab dan disebabkan kamu tetap mempelajarinya.

Ayat di atas merupakan penguatan terhadap merdekanya manusia dari perbudakan. Kemerdekaan beraqidah dikuatkan dengan Al-Qur'an Surat al-Baqarah ayat 256:

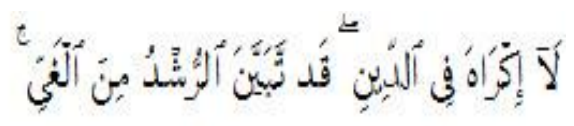

Artinya: tidak ada paksaan untuk (memasuki) agama (Islam); Sesungguhnya telah jelas jalan yang benar daripada jalan yang sesat.

Kemudian kebebasan berpikir dan berpendapat, diperkuat dengan surat Al-Baqarah ayat 260:

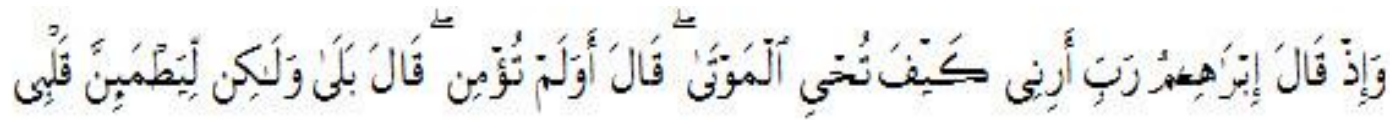

Artinya: "Dan (ingatlah) saat Ibrahim berkata: Ya Tuhanku, perlihatkanlah kepadaku bagaimana engkau menghidupkan orang-orang mati. Alloh berfirman; "Apakah kamu belum percaya?" Ibrahim menjawab; saya telah percaya, akan tetapi sipaya bertambah tenang hati saya"

Selanjutnya kemerdekaan dalam berkehendak diperkuat dengan surat An-Najm ayat 39-42 yang berbunyi: 


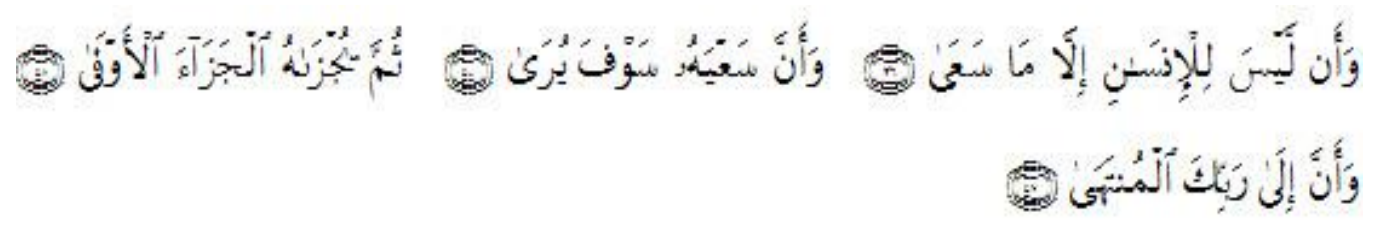

Artinya: "Dan bahwasanya seorang manusia tiada memperoleh selain apa yang telah diusahakannya. Dan bahwasanya ushanya itu kelak akan diperlihatkan (kepadanya). Kemudian akan diberikan balasan yang paling sempurna. Dan bahwasanya kepada Tuhanmulah kesudahan (segala sesuatu)".

Pemikiran tokoh diatas sejalan dengan fitrah manusia layaknya yang dideskripsikan dalam Al-Qur'an surat Ar-rum ayat 30, ("Maka hadapkanlah wajahmu kepada Agama dengan selurus-lurusnya, (sesuai dengan kecenderungan aslinya); itulah fitrah Alloh, yang Alloh menciptakan manusia diatas fitrah itu. Itulah agama yang lurus. Namun kebanyakan orang tidak mengetahuinya") ini bisa dipahami bahwa manusia merupakan ciptaan Allah yang memiliki kecenderungan asli atau dengan istilah lain memiliki "potensi dasar" yang memiliki, maka dari itu dikenal dengan "fitrah". Maka tidak keliru jika dikatakan oleh Prof. DR. H. Ramayulis dan DR. Samsul Nizar, MA dalam Filsafat Pendidikan Islam, 2009 bahwa fitrah adalah "kemampuan dasar dan kecenderungan yang murni bagi setiap individu". Dalam pengertian yang lebih luas bahwa fitrah sebagai sekumpulan hal yang telah dan sampai sekarang dikenal dengan kemanusiaan. Ini berarti bahwa pendidikan dijalankan untuk mengabdi pada nilai-nilai kemanusiaan yang keberadaannya bisa dirasakan tidak hanya oleh individu, tetapi juga oleh masyarakat.

Pada kajian lain dijelaskan bahwa fitrah memiliki kecenderungan yang netral. Kajian ini diperkuat dengan Firman Allah pada surat AnNahl Ayat 78 "Dan Alloh mengeluarkan kamu dari perut ibumu tidaklah mengetahui sesuatu apapun, dan ia menjadikan bagimu pendengaran, penglihatan dan hati" dan pada hadits Abu Hurairah meriwayatkan "tidaklah seorang anak dilahirkan kecuali atas dasar fitrah, maka kedua orangtuanya yang menjadikan mereka Yahudi atau Nasrani", fitrah manusia bisa diketahui dari Qur'an dan Hadits bahwa fitrah dipengaruhi dari aspek luar/eksternal berupa pengaruh dari luar diri anak. Fitrah dan aspek eksternal ini akan selalu membangun dialektika, sehingga memunculkan pengetahuan baru. Melalui ayat dan Hadits ini juga akan diketahui bahwa nyatanya pendidikan harus konsisten dalam membangun interaksi dengan kenyataan/realitas yang ada.

Maka sangat jelas bahwa antara teori fitrah yang oleh Islam 
dikembangkan dan pendidikan yang membebaskan yang telah dikembangkan oleh beberapa tokoh mempunyai suatu hubungan/koherensi dan sinegritas, dimana keduanya memiliki cara pandang terhadap manusia sebagai subjek dalam pendidikan dan bahwa humanisasi ini merupakan bagian dari proses inti dalam pendidikan (Paulo Freire).

Maka adanya hal tersebut, pendidikan Islam menjadi bagian dari proses pendidikan yang ada di Indonesia, dilihat sangat perlu dalam rangka mengkonsepkan dirinya dengan pendidikan yang bersifat memerdekakan. Dengan adanya pendidikan yang memerdekaan dalam pendidikan Islam ini, peserta didik dinantikan tidak hanya tahu dan mempraktekkan, tetapi juga dicerna secara kritis, serta mampu analisisnya secara rasional, tidak hanya sekedar tahu tetapi juga paham. Dengan demikian peserta didik tidak hanya fokus pada budaya berpikir magis dan naif, tetapi juga dapat melangkah pada budaya berpikir kritis. Hal inilah yang kiranya perlu dikembangkan dalam pendidikan Islam yang bersifat memerdekakan baik kepada pendidik ataupun peserta didik.

\section{Pandangan Tentang Manusia}

Menurut Freire, manusia yang utuh yaitu manusia sebagai subjek atau peran, bukan sebagai objek atau sasaran. Maka dari itu pendidikan yang memeerdekaan memposisikan pendidik dan peserta didik dalam situasi belajar bersama. Guru sebagai fasilitator dan siswa harus bertanggung jawab aktif dalam pembelajaran. Dalam pandangan Islam manusia merupakan makhluk ciptaan Tuhan yang mempunyai kecondongan asli atau dengan bahasa yang lain memiliki "potensi dasar" yang dimiliki, dan dikenal dengan istilah " $f i t r a h "$.

\section{Implementasi Pendidikan yang Memerdekakan/Membebaskan}

Dalam pelaksanaan pendidikan Islam yang memerdekakan, maka penulis bertitik tolak pada fondasi pemikiran yang sudah disampaikan sebelumnya, maka tahap-tahap metodik yang diambil adalah sebagai berikut:

1. Berorientasi pada kepentingan bersama.

2. Tujuannya yaitu membangun pemikiran "Human Dignity" atau ngewongke dalam istilah Jawa, dalam bahasa Indonesia yaitu memanusiakan manusia dan mengganti struktur masyarakat supaya dapat memenuhi kebutuhan setiap orang yang menjadi anggotanya.

3. Materi pendidikan yang ditransfer ada integrasi keilmuannya. 
4. Metode belajar: komunikatif dan dialog

5. Perlakuan terhadap peserta didik dan masyarakat yang belajar yaitu memerdekakan mereka dari berbagai tindakan baik itu penindasan, penghisapan dan penyelewengan.

6. Pola pendekatan kemanusiaan dan demokrasai

7. Manusia memposisikan aktif dan tanggungjawab dan dapat menjadi dirinya sendiri, sedangkan guru adalah sebagai fasilitator

8. Tempat belajar adalah kehidupan nyata sehari-hari.

9. Formasi belajar dibuat model komunikatif dimana peserta didik dan pendidik duduk bersama dengan formasi melingkar karena setiap orang adalah sumber belajar.

10. Quota orang yang belajar umumnya kecil, untuk membangun suasana komunikatif dan belajarnya lebih intensif dari pengalaman peserta didik langsung.

11. Setelah memiliki profesi/pekerjaan diminta tanggung jawab dan memihak pada masyarakat disekitarnya, terutama masyarakat yang masih miskin dan terbelakang.

Melalui beberapa langkah di atas, pendidikan Islam diidam-idamkan menjadi media yang mampu mencerdaskan, mendewasakan, memerdekakan dan ngewongke. Sehingga bisa disebut bahwa pendidikan adalah pemanusiaan, pembudayaan dan internalisasi nilai-nilai, baik bersumber dari pendidik maupun peserta didik. Kondisi demikian seirama dengan model pembelajaran yang sudah dikembangkan UNESCO (United Nations Educational Scientific, and Cultural Education) yang menjadi visi dasar pendidikan abad-21, yaitu "Learning How to Think, Learning How to do, Learning to be, Learning how to Live dan Learning How to Learn ".

\section{Analisis Kritis}

Berangkat dari teori pendidikan yang memerdekakan yang dikemukan Paulo Freire disebutkan bahwa, sebagai sebuah praksis sosial, pendidikan berupaya memberikan pertolongan dalam membebaskan manusia didalam kehidupan objektif dari penindasan yang mencekik mereka. Baginya fitrah mausia adalah menjadi subjek, bukan penderita atau objek. Sehingga pendidikan haruslah berorientasi kepada pengenalan realitas diri manusia dan dirinya sendiri. Pengenalan itu tidak cukup hanya bersifat objektif atau subjektif, tetapi harus kedua-duanya. Kebutuhan objektif untuk merubah keadaan yang tidak manusiawi selalu memerlukan kemampuan subjektif dan kemampuan objektif adalah suatu fungsi dialektis yang ajeg (constant) dalam diri manusia dalam hubungannya dengan kenyataan yang saling bertentangan yang harus difahaminya. 
Dalam Islam dikenal dengan beberapa kebebasan yang merupakan fitrah bagi setiap manusia, diantara kebebasan-kebebasan tersebut adalah merdeka dalam berakidah, merdekan dalam berpikir, merdeka dari kemiskinan dan merdeka dari ketakutan. Sedangakan menurut Ali Abdul Wahid Wafi yang dukutip Warid Khan mengemukakan adanya empat macam kebebasan yang mendasar dalam Islam, yaitu Al-hurriyah Almadaniah (kebebasan berbudaya), Al-hurriyah Ad-diniyyah (kebebasan beragama), Hurriyah at-tafkir wa at-ta'bir (kebebasan berfikir dan berpendapat) dan al-Huriyyah As-siyasiyyah (kebebasan politik).

Beberapa kebebasan yang dikemukakan ini,menjadi indikator dan cukup bukti untuk mengatakan bahwa Islam adalah sebagai agama pembebasan. Islam telah mengajarkan kepada manusia bagaimana kebebasan berpikir sesuai dengan ortodoksi keagamaan. Sebagai implikasinya, Islam mendefinisikan kebenaran (AI-haq) sebagai hal yang umum, yakni mencakup kaum muslimin dan non muslimin.

Ada pandangan lain dari Kuntowijoyo menyatakan bahwa sesungguhnya misi Islam yang penting adalah pembebasan. Dalam kontek dunia modern, hal ini berarti bahwa Islam harus membebaskan manusia dari kungkungan aliran pikiran yang menganggap manusia tidak mempunyai kemerdekaan dan hidup dalam absurditas. Ia mengkritik pembebasan ala barat yang mempunyai logika filsafat, bahwa kemajuan hanya dapat dicapai jika membebaskan diri dari alam pikiran agama, dan karena logika filsafatnya mengesampingkan referensi transedental, akhirnya mereka kehilangan petunjuk. Oleh karena itu, untuk merombak semuanya itu Islam harus melakukan revolusi, yaitu suatu revolusi untuk pembebasan.

Jika dicermati secara serius, sebenarnya Islam adalah agama yang toleran dan demokratis. Hal ini dikarenakan mampu untuk hidup bersama dengan berbagai peradaban dan kebudayaan. Kehadiran Islam yang tetap eksis kapan saja dan dimana saja. Dengan kebebasan ini pula, Islam memiliki keteguhan yang tinggi, bahwa memberi tempat yang mulia kepada ilmu pengetahuan dan teknologi. Disamping itu juga Islam adalah agama yang mampu menyatukan kebebasan-kebebasan dan peraturan-peraturan, individualisme dan evolusi, masa lalu dan masa kini, pelestarian dan pembaharuan, Islam dan kemanusiaan.

Berdasakan beberapa penyataan di atas, seharusnya pendididkan Islam mampu melakukan terobosan yang mengarah pada kondisi pembebasan, namun tetap menyatu pada agama. Jika dikaji dengan seksama, sebenarnya terdapat dua pengaruh pokok yang sangat erat hubungannya yang menunjukan bahwa antar Islam dengan pendidikan tidak bisa di pisah-pisahkan dan keduanya ini dapat dijadikan kaca mata untuk melihat mengapa Islam begitu berjaya dimasa lalu. Kedua 
pengaruh tersebut dapat dijelaskan sebagai berikut; pertama, senantiasa dilakukan rekonstruksi dan reinterpretasi pemilkiran Islam dengan menggunakan berbagai pendekatan disiplin ilmu, termasuk didalamnya ilmu filsafat. kedua, senantiasa dilakukan reformasi sistem pendidikan, baik yang bersifat institusional maupun yang bersifat konseptual.

Ketika pendidikan Islam dilihat sebagai upaya memerdekakan manusia, maka terdapat dua konteks pemaknaan yaitu: pertama, pendidikan harus dipahami dalam posisinya secara demokratis, yakni pelaksana pendidikan harus dilakukan secara demokratis, terbuka dan komunikatif. Kedua, pendidikan Islam sebagai proses internalisasi nilainilai ke-Islaman atau transfer of Islamic value. kata kunci dari nilai-nilai keIslaman itu adalah keyakinan/Tauhid yang menujukan pada pengertian bahwa tidak ada penghambaan kepada selain Alloh SWT, bebas dari belenggu kebadanan dan kerohanian. Islam sebagai sistem tauhid inilah yang merupakan dasar ontologis bagi pengembangan landasan aksiologis Islam sebagai sistem normatif dan landasan epistemologis (Islam sebagai sistem pengetahuan) kalau dengan kata kunci ini, Islam secara transparan menghendaki dan menciptakan persamaan, maka pendidikan Islam harus dipahami sebagai pembebasan proses pembebasan manusia untuk tidak merasa ada diskriminasi antar individu atau kelompok, dikuasai, ditindas ataupun diperbudak.

Kerangka dasar kebebasan ini adalah bahwa manusia itu merupakan makhluk yang memiliki kehendak bebas (free will). Istilah kebebasan di gunakan lebih dalam konteks manusia sebagai individu atau pribadi. Kebebasan merupakan sifat dasar manusia. Kebebasan merupakan tanda yang memberikan ciri khas pada kodrat manusia. Manusia dapat menjadi dirinya apabila ia dapat mengaktualisasikan potensi bebasnya. Demikian sebaliknya bahwa manusia belum sungguh-sungguh menjadi dirinya, jika tanpa kebebasan. Dengan demikianlah kebebasan menjadi hal yang teramat penting dan merupakan harta yang paling berharga dalam kehidupan manusia. Namun sering dengan perkembangan ilmu pengetahuan dan teknologi, sebagai wujud globalisasi yang disertai kemajuan diberbagai sektor kehidupan, kebebasan tidak lagi menjadi barang yang paling berharga yang menandai eksistensi seorang manusia. Teknologi dengan segala pirantinya telah mengikis habis kebebasan manusia. Dari sini, manusia justru menjadi budak-budak teknologi. Ia tidak dapat lagi menentukan dan mengarahkan hidupnya atas dasar kemauannya sendiri.

\section{Simpulan}

Problematikan pendidikan Islam bukan hanya masalah rendahnya mutu pendidik, penghargaan yang diberikan dan masalah teknis belaka, 
namun merupakan masalah yang kompleks. Pemerintah dan masyarakat berharap pendidikan yang membebaskan mampu mengembangkan potensi peserta didik. Sekolah atau madrasah jangan dijadikan benteng kekuasaan yang mematikan kreativitas siswa dan menjadikan terbelenggu oleh aturan yang dipaksakan.

\section{Referensi}

Al-Asqolani, Ahmad bin Ali bin Hajar, Tahdzibu al Tahdzib, Bairut: Muassatur Risalah, 1996.

Agus Wibowo, Malpraktik Pendidikan, Yoyakarta: 2008.

Mustofa Setiawan, Pendidikan Agama Islam Yang Membebaskan, wordpress.com, diakses pada tanggal 8 November 2013.

Paulo Freire dalam Siti Murtiningsih, Pendidikan Alat Perlawanan: Teori Pendidikan Radikal Paulo Freire, Yogyakarta: Resist Book, 2004.

Paulo Freire, Pendidikan Kaum Tertindas, Jakarta: LP3S, 2008. 